\title{
MISSION ACCOMPLISHED? FIFTY-FOUR YEARS OF SUFFERING FOR THE PEOPLE OF THE MARSHALL ISLANDS AND THE LATEST ROUND OF ENDLESS RECONCILIATION
}

\section{INTRODUCTION}

When viewed from a modern perspective of political correctness, U.S. history contains at least two well-known and unfortunate chapters: the reprehensible treatment of the Native Americans ${ }^{1}$ and the barbaric industry of slavery. ${ }^{2}$ Although one may dismiss the disturbing events of those eras as the distant past, a less known and more recent period of unpleasant history involved the United States mistreating the indigenous people of the Marshall Islands. ${ }^{3}$ From 1946 to 1958 , the Marshallese people ${ }^{4}$ endured sixty-seven experimental nuclear tests, ${ }^{5}$ conducted by the United States, that

1. For insight into the U.S. government's treatment of the North American Indians see WENDELl H. OSWALT, THIS LAND WAS THeIRS (2d ed. 1973).

2. For an overview of slavery in the United States see CHARLES JoHNSON \& PATRICIA SMITH, AFRICANS IN AMERICA: AMERICA'S JOURNEY THROUGH SLA VERY (1998).

3. See generally JANE DibBlin, DAy OF Two SunS: U.S. NUCLEAR TESTING AND THE PACIFIC ISLANDERS (1988). The Marshall Islands are located in the Pacific Ocean in the region known as Micronesia. See id. at 3. Micronesia also includes the Mariana Islands (now a U.S. Commonwealth), the Republic of Belau and the Federated States of Micronesia, made up of the Kosrae, Yap and Pohnpei islands. See id. Guam is also geographically part of Micronesia, but it is politically separate as a U.S. territory. See id. at 3 . The estimated population of the Marshall Islands in 1995 was 55,575. See RMI Online: Internet Guide to the Republic of the Marshall Islands, at http://www.rmiembassyus.org/popstat.html (last visited Sept. 10, 1999).

4. For an account of earlier history of the Marshallese people see FRANCIS X. HEZEL, S.J., THE FiRst TAINT OFCIVILIZATION: A HISTORY OFTHE CAROLINE AND MARSHALL ISLANDS IN PRE-COLONIAL DAYS, 1521- 1885 (1983). For subsequent history see JONATHAN M. WEISGALl, OPERATION CROSSROADS (1994).

5. See Welcome to the Nuclear Claims Tribunal, at http://www.tribunalmh.org/text.html (last visited Sept. 7, 1999) [hereinafter Claims Tribunal]. See also 143 CoNG. REC. H4334-01, H4335 (daily ed. June 24, 1997) (statement of Mr. Faleomavaega), available at 1997 WL 345477 (stating that between 1946 and 1958 the United States tested sixty-six atomic and hydrogen nuclear bombs at Bikini and Enewetak atolls in the Marshall Islands.) An "atoll" is "a ringlike coral island that encloses a lagoon." AMERICAN HERITAGE DICTIONARY 43 (1983).

Disagreement exists concerning whether sixty-six or sixty-seven tests were conducted in the Marshall Islands over this period. The U.S. government's position appears to be that sixtysix tests occurred. See The Status of Nuclear Claims and Relations and Resettlement in the Marshall Islands, 1999: Hearings Before the House Comm. On Resources, 106th Cong. (1999) (statement of Ralph Boyce, Deputy Assistant Secretary, Bureau of East Asian and Pacific Island Affairs for Department of State), available at 1999 WL 16947528 [hereinafter Boyce testimony]. See also The Status of Nuclear Claims and Relations and Resettlement in the Marshall Islands, 1999: Hearings Before the House Comm. On Resources, 106th Cong. (1999) 
damaged the health of many Marshallese citizens and forced a significant number of them from their homes. ${ }^{6}$ The most infamous device, code-named "Bravo," produced a crater 6240 feet in diameter and 164 feet deep, illustrating the devastating force of these tests.'

Although it is tempting to simply categorize the events surrounding the U.S. nuclear testing imposed on the Marshall Islands as yet another shameful chapter in U.S. history, that categorization may be too hasty. Even supporters of the Marshallese people acknowledge that the arsenal developed during the testing program provided the powerful nuclear deterrent responsible for victory in the Cold War. ${ }^{8}$ Justifications for the tests, however, are beyond the scope of this note.

What remains is over half-a-century of suffering by the Marshallese people due to intentional acts by the U.S. government. Although the United States accepted responsibility for its actions in the Compact of Free Association between the United States and the Republic of the Marshall Islands (Compact), ${ }^{9}$ the provisions of that agreement have proven inadequate to fully repay the Marshallese citizens for the damage done to their homeland or to provide for their medical care. ${ }^{10}$ Accordingly, the Republic of the Marshall Islands (RMI) announced its intention to submit to the U.S. Congress a request for additional funding, a process provided in the Changed Circumstances provision ${ }^{11}$ of the Section 177 Agreement, a

(statement of Allen P. Stayman, Director of the Office of Insular Affairs of the Department of the Interior), available at 1999 WL 16947529(reiterating that sixty-six tests were conducted) [hereinafter Stayman testimony]. The Republic of the Marshall Islands, however, cites sixtyseven tests in its official tally. See Claims Tribunal, supra note 5.

6. See DibBlin, supra note 3, at 255-58. For a chronological summary of the tragic events see id.

7. See U.S. Nuclear Testing Program in the Marshall lslands, at http://www.tribunalmh.org/testing.html (last visited Sept. 7, 1999) [hereinafter Nuclear Testing Program].

8. See 143 CONG. REC. H4334-01, H4335 (daily ed. June 24, 1997) (statement of Mr. Faleomavaega), available at 1997 WL 345477. See generally WEISGALL, supra note 4 (describing the Cold War fears and intra-military rivalries that fueled the testing program).

9. Compact of Free Association, Pub. L. No. 99-239, 99 Stat. 1770 (1986).

10. See 143 CONG. REC. H4334-01, H4335 (daily ed. June 24, 1997) (statement of Mr. Faleomavaega), available at 1997 WL 345477. See also 145 CONG. REC. H3063-02, H3064 (daily ed. May 12, 1999) (statement of Mr. Faleomavaega), available at 1999 WL 296150 (stating that the people of the Marshall Islands have endured great harm that continues today); 145 CONG. REC. H8115-03, H8116 (daily ed. Sept. 13, 1999) (statement of Mr. Underwood), available at 1999 WL 708989 (explaining how some Marshallese lost their homes to the testing and have not been able to return).

11. Section 177 Agreement, Article IX, Changed Circumstances provides:

If loss or damage to property and person of the citizens of the Marshall Islands, resulting from the Nuclear Testing Program, arises or is discovered after the effective date of this Agreement, and such injuries were not and could not reasonably have been identified as of the effective date of this agreement, and if such injuries render the provisions of this Agreement manifestly inadequate, the Government of the Marshall Islands may request that the Government of the 
subsidiary agreement which implemented Section $177^{12}$ of the Compact. ${ }^{13}$ The RMI claims that the funding provided by the Section 177 Agreement is "manifestly inadequate," an allegation based in part on the assertion that needs were underestimated because the U.S. Department of Energy withheld

United States provide for such injuries by submitting such a request to the Congress of the United States for its consideration. It is understood that this Article does not commit the Congress of the United States to authorize and appropriate funds.

Id.

12. The Compact of Free Association, Pub. L. No. 99-239, 99 Stat. 1770 (1986), art. VII, $\S 177$ provides:

(a) The Government of the United States accepts the responsibility for compensation owing to citizens of the Marshall Islands, or the Federated States of Micronesia (or Palau) for loss or damage to property and person of the citizens of the Marshall Islands, or the Federated States of Micronesia, resulting from the nuclear testing program which the Govemment of the United States conducted in the Northern Marshall Islands between June 30, 1946, and August 18, 1958.

(b) The Government of the United States and the Government of the Marshall Islands shall set forth in a separate agreement provisions for the just and adequate settlement of all such claims which have arisen in regard to the Marshall Islands and its citizens and which have not as yet been compensated or which in the future may arise, for the continued administration by the Government of the United States of direct radiation related medical surveillance and treatment programs and radiological monitoring activities and for such additional programs and activities as may be mutually agreed, and for the assumption by the Government of the Marshall Islands of responsibility for enforcement of limitations on the utilization of affected areas developed in cooperation with the Government of the United States and for the assistance by the Government of the United States in the exercise of such responsibility as may be mutually agreed. This separate agreement shall come into effect simultaneously with this Compact and shall remain in effect in accordance with its own terms.

(c) The Government of the United States shall provide to the Government of the Marshall Islands, on a grant basis, the amount of $\$ 150$ million to be paid and distributed in accordance with the separate agreement referred to in this Section, and shall provide the services and programs set forth in this separate agreement, the language of which is incorporate[d] into this Compact.

Id.

13. See, e.g., The Status of Nuclear Claims and Relations and Resettlement in the Marshall Islands: Hearings Before the House Comm. On Resources, 106th Cong. (1999) (statement of Tony A. Debrum, Minister of Finance, House Resources Marshall Islands) [hereinafter Tony A. Debrum testimony](stating that the RMI is preparing to submit a request for additional funding under the Changed Circumstances provision). See infra Part IV.B discussion of the relationship between the Compact and the Section 177 subsidiary agreement. 
substantial information from the RMI at the time of the Compact's formation. ${ }^{14}$

This note seeks to analyze the RMI's allegation that the provisions of the Compact and Section 177 Agreement are manifestly inadequate, and subsequently to examine whether Congress should grant additional funding to address the alleged harm that has arisen from the nuclear testing. Part II of this note explains how the United States arrived at its present position of culpability by abusing a former trust relationship with the Marshall Islands. Part III provides background information on the Marshallese injuries and suffering caused by the nuclear testing. Part IV examines the United StatesRepublic of the Marshall Islands Compact of Free Association and subsidiary Section 177 Agreement. Part V analyzes current allegations of inadequacy of the Compact and Section 177 Agreement. Part V also addresses the implications, to that analysis, of the U.S. Department of Energy's withholding of information. Finally, Part VI recommends that the U.S. Congress conduct a prompt evaluation of whether or not to grant additional funding to the Marshall Islands. That evaluation should result in granting needed funds due to the United States' fiduciary and moral obligations.

\section{THE UNITED STATES AS TRUSTEE}

At the conclusion of World War II, the United Nations wanted to aid the development of the newly liberated peoples in Africa and Micronesia. ${ }^{15}$ To accomplish that goal, the United Nations established the International Trusteeship System, ${ }^{16}$ under which members of the United Nations administered the trusteeship states. ${ }^{17}$ The Trusteeship System required the trustees to help the trust territories develop autonomous systems of

14. See 145 CONG. REC. H3063-02, H3064 (daily ed. May 12, 1999)(statement of Mr. Faleomavaega), available at 1999 WL 296150 (stating that recent declassified DOE documents show that the U.S. government has not always been candid with the RMI); 145 CoNG. REC. H8115-03, H8117 (daily ed. Sept. 13, 1999) (statement of Mr. Miller), available at 1999 WL 708989 (explaining that it was the Bush administration that released previously confidential information to the RMI).

15. See Hyun S. Lee, Post Trusteeship Environmental Accountability: Case Of PCB Contamination On The Marshall lslands, 26 DENV.J. INT'L.L. \& POL'Y 399, 399 (1998). The Marshall Islands had previously been held as a trust territory by the Japanese under the League of Nations Mandate System. See id. at 403. At the end of World War II, the United Nations replaced the League of Nations and replaced the Mandate System with the International Trusteeship System. See id. at 403-04. As in the League of Nations Covenant, the nation-states that accepted a United Nations Trusteeship accepted "a sacred trust to promote the well being of the inhabitants of the Trust." ld. at 404.

16. See U.N. CHARTER art. 75.

17. See Lee, supra note 15 , at 404 . See also Juda v. United States, $13 \mathrm{Cl}$. Ct. 667, 670-74 (1987) (detailing background information on the Marshall Island as a trust territory in the United Nations system). 
government and to aid in the trust territories' economic development. ${ }^{18}$ United Nations members who accepted the trusteeship responsibility also acknowledged a "sacred trust obligation" whose beneficiaries were the trust territory's inhabitants. ${ }^{19}$ In general, the United Nations granted trustees expansive authority in administering the trust territories. ${ }^{20}$

The United States controlled the Marshall Islands at the end of World War $\mathrm{II}^{21}$ and arranged for their designation as a strategic trust. ${ }^{22}$ The Trusteeship Agreement ${ }^{23}$ that the United States entered into with the United

18. See Lee supra note 15 , at 399 . For a current overview of the RMI economy see Marshall Islands: Country Profile, ASIA \& PAC. REV. WORLDOFINFO., Nov. 1, 1998, available at 1998 WL 26760534. See also Interview with Chief Secretary Oscar Debrum, MICRONESIAN INVESTMENT Q., June 1, 1992, available at 1992 WL 3170273 (explaining the RMI's current strategies for economic growth).

19. Lee, supra note 15 , at 404 .

20. See id.

21. See Dibblin, supra note 3, at 17. The United States captured Micronesia from the Japanese in the autumn of 1944 after more than two years of what are widely described as some of the "bloodiest battles witnessed in the Pacific during the Second World War." Id. at 17. Approximately five thousand Micronesians, $10 \%$ of the estimated population, died during those battles. Id.

22. See Lee, supra note 15 , at 403 . The administering authority of a strategic trust had greater control over the territory than a non-strategic trust. See id. Article 82 of the United Nations Charter provides for strategic trusts. U.N.CHARTER art. 82. Article 83(2) provides that "It]he basic objectives set forth in Article 76 shall be applicable to the people of each strategic area." U.N. CHARTER art. 83(2). Article 76 provides in full:

The basic objectives of the trusteeship system, in accordance with the Purposes of the United Nations laid down in Article 1 of the present Charter, shall be:

a. to further international peace and security;

b. to promote the political, economic, social, and educational advancement of the inhabitants of the trust territories, and their progressive development towards self-government or independence as may be appropriate to the particular circumstances of each territory and its peoples and the freely expressed wishes of the peoples concerned, and as may be provided by the terms of each trusteeship agreement;

c. to encourage respect for human rights and for fundamental freedoms for all without distinction as to race, sex, language, or religion, and to encourage recognition of the interdependence of the peoples of the world; and

d. to ensure equal treatment in social, economic and commercial matters for all Members of the United Nations and their nationals, and also equal treatment for the latter in the administration of justice, without prejudice to the attainment of the foregoing objectives and subject to the provisions of Article 80.

\section{U.N. CHARTER art. 76.}

23. Trusteeship Agreement For the Former Japanese Mandated Islands, July 18, 1947, 8 U.N.T.S. 189 (1947). "The Trusteeship Agreement is a treaty in the nature of a bilateral contract between the Security Council and the United States." Juda v. United States, $13 \mathrm{Cl}$.Ct. 667. 671 (1987). Article 6 of the Trusteeship Agreement required the United States, in the discharge of its duties under Article 76(b) of the United Nations Charter, "to promote the 
Nations Security Council permitted the United States to deploy military forces in the Marshall Islands, construct military bases, and close off areas for security purposes. ${ }^{24}$ The United States took full advantage of this authority by using the Marshall Islands as a nuclear testing ground, while doing little in the first twelve years as trustee to accomplish the goals of the Trusteeship System as outlined by the United Nations. ${ }^{25}$

From June 30, 1946 to August 18, 1958, the United States conducted nuclear tests ${ }^{26}$ in the Marshall Islands. ${ }^{27}$ The most powerful of the tests, "Bravo,"28 released the explosive power of one thousand Hiroshima bombs. ${ }^{29}$ Bravo was part of the United States coordinated program of atomic and nuclear weapons testing conducted under the control of the Atomic Energy Commission (AEC) ${ }^{30}$ Because of the expansive control granted to the United States as trustee, U.S. military leaders and AEC officials took the actions they deemed necessary and then, on several occasions, withheld information that was damaging to their interests. ${ }^{31}$ This abusive relationship ${ }^{32}$ officially lasted until 1986 when the United States and the Marshall Islands terminated the trust relationship by signing the Compact of Free Association. ${ }^{33}$ Although a positive step toward correcting the harm

development of the inhabitants towards self-government or independence as may be appropriate to the particular circumstances of the territory and its peoples." Id. at 672.

24. See Lee, supra note 15, at 404.

25. See U.N. CHARTER art. 76, supra note 22.

26. For a complete listing of the tests in chronological order, detailing whether it was an atmospheric or underwater test see Nuclear Testing Program, supra note 7.

27. See id. For background on the selection process for the atomic testing location see Weisgall, supra note 4, at 32-33. Prior to commencing Operation Crossroads in 1946, military officials studied more than a dozen locations throughout the Pacific, Atlantic, and the Caribbean. See id. at 32 . The majority of these locations were eliminated because their waters were too shallow, the population too large, or the weather too unpredictable. See id.

28. Bravo was detonated on March 1, 1954, at Bikini atoll. See Nuclear Testing Program, supra note 7.

29. See id.

30. See The Status of Nuclear Claims and Relations and Resettlement in the Marshall Islands, 1999: Hearings Before the House Comm. On Resources, 106th Cong. (1999). During this same time period, the Atomic Energy Commission conducted nuclear weapons tests in the Nevada desert. See generally Elizabeth Louise Loeb, Constitutional Fallout From the Warner Amendment: Annihilating the Rights of Atomic Weapons Testing Victims, 62 N.Y.U. L. REV. 1331(1987) (explaining how the U.S. government faced allegations of using U.S. military personnel as guinea pigs and then hiding behind the Warner Amendment).

31. See infra Part V. for discussion on several incidents where U.S. officials deceived the RMI government.

32. In 1954, the Marshallese people submitted a petition to the United Nations pleading for it to stop the next round of hydrogen bomb experiments. See Lee, supra note 15, at 406. The testing, however, continued for four additional years. See Nuclear Testing Program, supra note 7.

33. See Compact of Free Association, Pub. L. No. 99-239, 99 Stat. 1770 (1986). PCB contamination of the Marshall Islands, caused by the United States bringing electrical equipment to the islands, presents another issue of post trusteeship accountability. See 
done, the Compact did not erase the consequences of the radiation exposure, which continue to this day.

\section{The Marshallese Suffering}

The Marshallese people suffered and continue to suffer physical and non-physical injuries as a result of the testing program. ${ }^{34}$ Tony A. Debrum, Minister of Finance for the Republic of the Marshall Islands, stated before the U.S. House of Representatives Resources Committee that " $[t]$ here is not a single soul in the Marshall Islands whose life remains untouched by the U.S. Nuclear Weapons Testing Program." 35 "Every Marshallese citizen has lost a family member or friend who died from a radiogenic illness." 36

\section{A. Physical Suffering}

The majority of the physical injuries traceable to the nuclear testing did not result from a one-time exposure to radiation. However, the extreme amounts of radiation released from $\mathrm{Bravo}^{37}$ caused acute injuries to particular victims in addition to contributing to the long-term physical injuries of the Marshallese people. ${ }^{38}$ In preparing for that test, scientists recommended that the Rongelap and Ailinginae atolls, several hundred miles east of the Bikini test site, be placed in the "danger zone ${ }^{39}$ for Bravo. ${ }^{40}$ The U.S. Interior Department, however, was reluctant to displace islanders, as was done

generally Lee, supra note 15 . In light of the former trust relationship, Lee questions whether the United States has a continuing fiduciary duty to remedy the environmental consequences of the trusteeship era that still linger. See id. at 400 . See infra Part VI. for discussion of the fiduciary duty the United States arguably owes to the Marshall Islands for the nuclear damage.

34. See 143 CONG. REC. H4334-01, H4335 (daily ed. June 24, 1997) (statement of Mr. Faleomavaega), available at 1997 WL 345477. See also 145 CONG. REC. H3063-02, H3064 (daily ed. May 12, 1999) (statement of Mr. Faleomavaega), available at 1999 WL 296150 (stating that the people of the Marshall Islands endured great harm that continues today); 145 CONG. REC. H81 15-03, H8116 (daily ed. Sept. 13, 1999) (statement of Mr. Underwood), available at 1999 WL 708989 (explaining that some Marshallese lost their homes because of the testing and have not been able to return).

35. Tony A. Debrum testimony, supra note 13.

36. Tony A. Debrum testimony, supra note 13. Radiogenic, as used in this note, generally refers to diseases associated with radiation exposure.

37. Bravo was the first deliverable hydrogen bomb detonated by the United States. See WEISGALL, supra note 4, at 302.

38. See WEISGALL, supra note 4, at 302. See also Endangered Islands, NEW STRAITS TIMES (MALAYSIA), Aug. 7, 1995, at 1 (explaining that only in recent years are the diseases and birth defects caused by the nuclear testing in Micronesia being fully realized).

39. "Danger zone" refers to the area of possible danger from the explosion or radiation. See WeISGALL, supra note 4, at 302.

40. See id. 
during the earlier Operation Crossroads. ${ }^{41}$ Accordingly, the Interior Department and the AEC drew the danger zone boundaries precisely to exclude those atolls. ${ }^{42}$

Bravo exploded with a force three times greater than its creators expected.$^{43}$ U.S. officials claimed that it was an "unpredicted" shift in wind direction $^{44}$ that sent the massive cloud of radioactive fallout eastward covering approximately seven thousand square miles. ${ }^{45}$ Fallout from the test showered 28 American servicemen on Rongerik, the 236 inhabitants of Rongelap and Utrik atolls, and other Marshallese camping at Ailinginae Atoll. ${ }^{46}$ The U.S. military evacuated the servicemen to Kwajalein Atoll the day after Bravo but did not rescue the people of Rongelap and Utrik for two to three days. ${ }^{47}$

The fallout exposed the Marshallese victims to radioactivity that equaled the dose received by Japanese citizens located less than two miles from ground zero at Hiroshima and Nagasaki. ${ }^{48}$ Almost all of the Rongelapese displayed the usual symptoms of radiation poisoning: hair loss, skin lesions, and lowered white blood cell counts. ${ }^{49}$ Seventeen of nineteen

41. See id. "Operation Crossroads" refers to the tests code-named "Able", detonated on June 30, 1946, and "Baker", detonated on July 24, 1946. See Nuclear Testing Program, supra note 7. Both of these tests were conducted at Bikini Atoll. See id. The inhabitants of Bikini Atoll had been evacuated for those tests. See WEISGALL, supra note 4, at 106-07.

42. See WEISGALL, supra note 4, at 302 . The Atomic Energy Commission took extensive precautions with regard to an explosive device prior to Bravo. See id. That weapon, codenamed "Mike," caused very little fallout, hence encouraging lax safety and emergency evacuation plans by the AEC for Bravo. See id.

43. See id. "Bravo was the most powerful nuclear weapon ever detonated by the United States and was, at the time, the largest man made explosion in the history of the world, equal to the force of about 750 Hiroshima bombs." Id. "Bravo had an explosive force of about fifteen megatons, or fifteen million tons of TNT." Id.

44. See id. at 303. See also Merril Eisenbud, Monitoring Distant Fallout: The Role of the Atomic Energy Commission Health and Safety Laboratory During the Pacific Tests, with Special Attention to the Events Following Bravo, Health PHySICS vol. 73, at 21, 26 (questioning whether the winds shifted or whether the "meteorological window" that existed was simply too narrow for safety) [hereinafter Eisenbud].

45. WEISGALL, supra note 4, at 303.

46. Id. at 303. A controversy ensued because the Bravo fallout al so injured twenty-three crewmen of the Japanese fishing vessel the Lucky Dragon. Id. One of the men died, causing public outrage in Japan. Id. See also Eisenbud, supra note 44, at 25 (discussing the ramifications of the unexpected group of Japanese victims).

47. See WEISGALL, supra note 4, at 303.

48. See id. at 304.

49. See id. See also E.P. Cronkite, M.D., DePT. Of Energy, Epilogue to Five Year REPORT ON THE MEDICAL FOLLOW UP OF MARSHALLESE RECEIVING SPECIAL MEDICAL CARE RELATED TO THE 1954 BRAVO FALLOUT RADIATION (JANUARY 1992-1996) DOE/EH-0593, at http://tis.eh.doe.gov/ihp/marsh/congress.html (last visited Oct. 10, 1999)(stating "[t]here had been nausea, vomiting and diarthea in some of the Marshallese ... [t]here is no question that the radiation was responsible for skin burns, epilation, temporary suppression of hemopoiesis, thyroid hypofunction, thyroid tumors, and probably responsible for the fatal case of acute 
Rongelapese who were under ten years old at the time of Bravo developed abnormal thyroid nodules. ${ }^{50}$ One member of that group died of leukemia. ${ }^{51}$ The Atomic Energy Commission tried to keep the disaster a secret ${ }^{52}$ and did not admit the gravity of the incident for decades. ${ }^{53}$

The injuries and pain caused by acute exposure represents only one portion of the physical injuries caused by the radiation exposure. Scientists and doctors continue to compile data on the non-acute exposure related illnesses, which are only now being identified and tallied due to the long latency periods, ${ }^{54}$ poor health care for the first generation of victims, ${ }^{55}$ and the emergence of a new generation of victims from subsequent exposure. ${ }^{56}$ RMI officials emphasize that sixty-six explosions other than Bravo ${ }^{57}$ contributed to radiation and trace chemicals on each of the Marshall Islands, raising the probability of diseases caused by non-acute exposure. ${ }^{58}$

The RMI continues to assess the total magnitude of the long-term injuries. Partially in response to devastating errors by U.S. officials, including prematurely resettling people to islands which were not safe, ${ }^{59}$ the

leukemia.")

50. See WeISGALL, supra note 4, at 304.

51. See id. at 303.

52. See id. When the information was uncovered and ended up in a Cincinnati newspaper, the AEC issued a statement claiming that "during the course of a routine atomic test," some Marshallese "were unexpectedly exposed to some radioactivity," but "there were no burns" and "all are reported well." Id. at 303-04.

53. See id. at 304. Not until 1982 did the U.S. government admit the truth about Bravo. See id. What the AEC characterized a "routine atomic test" became in the words of the Defense Nuclear Agency, "the worst single incident of fallout exposures in all the U.S. atmospheric testing program." Id. "[N]o burns" became "acute radiation effects." Id. It would later be uncovered that with full knowledge that winds were not headed northward to the open sea but due east over Bikini's islands, the AEC proceeded to detonate the Bravo bomb. See id.

54. See Endangered Islands, NEW STRATTS TiMES, Aug. 7. 1995, at 1. Only in recent years have the diseases and birth defects caused by the nuclear testing in Micronesia been fully realized. See id.

55. See infra Part V. B \& C for discussion of the quality of health care provided.

56. There has been a wealth of data collected on exposure since the nuclear testing ended. For a partial list of DOE studies that are available for public viewing see Health Physics - The Radiation Journal, at http://tis.eh.doe.gov/ihp/marsh/journal (last visited Oct. 8, 1999). The titles of these reports illustrate that it is not realistic for a layman to challenge the validity of the data based on complex science.

- 57. Bravo represented approximately one-seventh of the radiation released from the testing program. See Claims Tribunal, supra note 5.

58. See Tony A. Debrum testimony, supra note 13.

59. Some Bikinians returned to their atoll in 1969, a year after President Johnson announced that Bikini was safe for resettlement. See Hearings on S. 1804 Before the Senate Energy and Natural Resources Comm., 103d Cong. (1996) (statement of Jonathan M. Weisgall, Legal Counsel to the people of Bikini), available at 1996 WL 10829191 [hereinafter Weisgall testimony]. They lived there until 1978, when medical tests by U.S. doctors revealed that the people possibly ingested the largest amount of radioactive material of any known population, and that the people needed to leave immediately. See id. An Atomic Energy Commission panel 
RMI initiated the Marshall Islands Nationwide Radiological Study.$^{60}$ Several obstacles exist, however, to amassing the final tally of injuries. First, U.S. officials have primarily focused upon only those victims who were acutely exposed. ${ }^{61}$ Secondly, many of the radiation monitoring and medical reports were produced by the same agencies that have both withheld information and at certain points lied, thereby making it difficult for Marshallese citizens to trust the data. ${ }^{62}$ Third, an unknown quantity of information remains classified..$^{63}$ Finally, funding deficiencies limit the RMI's ability to collect additional data. ${ }^{64}$ As the RMI continues its efforts to collect the needed data, Marshallese citizens with injuries they believe to be related to the nuclear testing present their claims to the Nuclear Claims Tribunal, a court created by the Section 177 Agreement. ${ }^{65}$

\section{B. Non-Physical Injuries}

Aside from causing physical injuries and disease, the nuclear testing forced many Marshallese from their homes. ${ }^{66}$ The events surrounding the people of Bikini Atoll illustrate the plight of those Marshallese uprooted. The U.S. Navy removed the Bikinians from their atoll in 1946 to facilitate

relied on an erroneous 1957 AEC report when it told the President that Bikini was safe. See id.

60. See Bikini Atoll, What About Radiation on Bikini Atoll, at http://www.bikiniatoll.com/whatrad.html (last visited Nov. 18, 1999). See also Radiation Health Effects Research Resource, at http://radefx.bcm.tmc.edu/marshall_islands/_last visited Nov. 18, 1999) (explaining that the study was the first comprehensive radiological monitoring program of the Republic of the Marshall Islands (RMI)). The entire report is available for viewing at the Radiation Health Effects Research Resource web site. See id

In addition, the July 1997 issue of Health Physics was devoted entirely to the Consequences of Nuclear Testing in the Marshall Islands. See 73 Health PHysics, No. 1 (1997), available at http://tis.eh.doe.gov/ihp/marsh/journal.

61. See infra Part V.B for discussion of exposure.

62. See HEALTH PHYSICS - THE RADIATION JOURNAL, available at http://tis.eh.doe.gov/ihp/marsh/journal (last visited Oct. 8, 1999). "Because of what some would consider callous disregard and perhaps duplicity for the well-being of the residents of the Marshall Islands, they no longer trust our government to do the right thing." 145 CoNG. REC. H3063-02, H3064 (daily ed. May 12, 1999) (statement of Mr. Faleomavaega), available al 1999 WL 296150.

63. See Nuclear Claims Tribunal: Approach to Compensation, at http://www.tribunalmh.org/appro.html(visited Nov. 5, 1999) [hereinafter Claims Approach].

64. See The Status of Nuclear Claims and Relations and Resettlement in the Marshall Islands, 1999: Hearings Before the House Comm. On Resources, 106th Cong. (1999) (statement of Oscar Debrum, Chairman of the Nuclear Claims Tribunal), available at $1999 \mathrm{WL}$ 16947535 [hereinafter Oscar Debrum testimony].

65. See infra part V.D for discussion of the Nuclear Claims Tribunal.

66. See Boyce testimony, supra note 5. See also 145 CoNG. REC. H8115-03, H8116 (daily ed. Sept. 13, 1999) (statement of Rep. Underwood), available at 1999 WL 708989 (speaking specifically of the Bikinians' forced exile from their atoll). 
the U.S. nuclear testing program. ${ }^{67}$ U.S. officials placed the Bikinians on Rongerik, an uninhabited atoll approximately one-hundred miles from Bikini. ${ }^{68}$ Naval officials falsely stated that Rongerik was larger and "richer" than Bikini. ${ }^{69}$ Contrary to the Navy's assertions, Rongerik's land area was one-quarter of the size of Bikini, and its pandanus and coconut trees produced considerably less fruit than those of Bikini. ${ }^{70}$

After a two-year stay on Rongerik Atoll that resulted in near starvation, ${ }^{71}$.U.S. officials moved the Bikinians to Kwajalein Atoll. For their six month stay on Kwajalein, they lived in tents beside a runway used by the U.S. military. ${ }^{72}$ As early as 1948 , the official Naval history of the Trust Territory, in reference to the Bikini Islanders, reported that "[d]efinite physiological scars were left on the people. ${ }^{\text {73 }}$ In November 1948, U.S. officials relocated the Bikinians to Kili Island, which is approximately fourhundred miles south of Bikini. ${ }^{74}$ Clearly contrary to the Trusteeship System's goals, "[i]n less than three years, the once self-sufficient people had been transformed into dependent wards of the United States. $" 75$ Since their arrival in Kili in 1948, the Bikinians have compared it to a jail. ${ }^{76}$ Most Bikinians

67. See WEISGALL, supra note 4, at 109. There is no precise record of what the Navy told the Bikinians when they first "asked" them if they would move. See id. The evidence, however, strongly suggests that the Bikinians believed their departure was to be temporary. See id.

68. See 145 CONG. REC. H8115-03, H8116 (daily ed. Sept. 13, 1999) (statement of Rep. Underwood), available at 1999 WL 708989.

69. Id.

70. Id.

71. See id.

72. See id. For details on the Bikinians' journey see Jack Niedenthal, A History of the People of Bikini Following Nuclear Weapons Testing in the Marshall Islands: With Recollections and Views of Elders of Bikini Atoll, 73 HEATH PHYsics 28-36 (1997).

73. 145 CONG. REC. H8115-03, H8116 (daily ed. Sept. 13, 1999) (statement of Rep. Underwood), available at 1999 WL 708989.

74. See id.

75. Id.

76. See id. The RMI and the DOE currently are resolving the safety status of Bikini Atoll, as well as Eniwetak, Rongelap, and Utrik atolls. See The Status of Nuclear Claims and Relations and Resettlement in the Marshall lslands: Hearings Before the House Comm. On Resources, 106th Cong. (1999) (statement of Paul J. Seligman, Deputy Assistant Secretary for Health Studies of Department of Energy), available at 1999 WL 16947531 [hereinafter Seligman testimony]. Seligman summarized the DOE's position:

The Utrik people can choose to live on their atoll without concern that their health will be affected by radiological exposure. The Rongelap people could choose to resettle without concern that their health will be affected by radiological exposure if they 1) conducted a limited scrape of surface soils in the village areas and 2) apply potassium fertilizer to areas where food is growing. This mitigation technique, referred to as the combined option, is the basis for the resettlement program being implemented at Rongelap today. We have recently entered into a Memorandum of Understanding with the Rongelap leadership to provide radiological monitoring of the ongoing resettlement activities. The 
remain there today, unable to return home. ${ }^{7}$

The weapons testing inflicted additional non-physical injuries on the Marshallese people by reducing their homeland to a nuclear wasteland. ${ }^{78}$ Prior to the testing, the Marshallese people enjoyed a close relationship to their islands and atolls, each of which sustained some level of environmental degradation as a result of the nuclear testing. ${ }^{79}$ The environmental damage sustained by some atolls continues to render food that is grown there lethal. ${ }^{80}$ Fifty-four years after the nuclear testing began, radiation prevents many islanders from safely returning home because they would be subjected to continuos exposure from the soil, water, and air. ${ }^{81}$ In a fate worse than contamination, the nuclear tests destroyed some islands completely. ${ }^{82}$ As stipulated under the Section 177 Agreement, Marshallese citizens may submit claims for these property damages to the Nuclear Claims Tribunal. ${ }^{83}$

Bikini people could choose to resettle without concern that their health will be affecte by radiological exposure if they, like the Rongelap, 1) scrape the village areas and 2) apply potassium fertilizer to food growing areas. The Enewetak people have been resettled on Enewetak atoll. Bioassay and whole body counting results have confirmed that radiation doses on Eniwetak Island, where resettlement has occurred, are at or near world background levels and present no health consequences to the population. If the Enewetak people decide to, resettle Enjebi Island, DOE recommends using the combined option as at Rongelap and Bikini atolls for mitigation.

Id.

77. See 145 CONG. REC. H81 15-03, H8116 (daily ed. Sept. 13, 1999) (statement of Rep. Underwood), available at 1999 WL 708989.

78. See id. The Bikini culture, society, and personal identity are rooted in their ancestral home: the islands, reefs, and lagoon of Bikini Atoll. See id. "Short of loss of life itself, the loss of their ancestral homeland represented the worst calamity imaginable for the Bikini people." Id.

79. See Tony A. Debrum testimony, supra note 13.

80. See Assessing Exposure to Radiation, at http://www.llnl.gov/str/Robison.html (last visited October 10. 1999). For a list of fifty-seven DOE documents and studies relating environmental data collected on the Marshall Islands see Intemational Health Programs -Marshall Islands Environmental Documents, available at http://tisnt.eh.doe.gov/ihp/marsh/env_docs.html (last visited Oct. 8, 1999).

81. See LaWRENCE Livermore National LaboRatory, Health and ECOlOgical ASSESSMENT DIVISION , AN UPDATED DOSE ASSESSMENT FOR RONGELAP ISLAND UCRL-LR107036 (July 1994) (written by William L. Robison, et al.).

82. See WEISGALL, supra note 4, at 307 . Some islands were totally obliterated. See id. In 1952, the AEC did not send the Bikinians home because "[i]t is possible that the tests planned for Eniwetak may result in the destruction of a part or all of the atoll ... . " Id. at 301 . That year "Mike" confirmed the AEC's fears by completely destroying Elugelab Island. See id. Subsequently, the 1956 "Zuni" device "vaporized most of the westem end of Bikini's Eneman Island." See id. at 307. Accordingly, it is physically impossible for some Marshallese to ever "return home."

83. See infra Part V.D for discussion of the Nuclear Claims Tribunal. 


\section{The CoMpact of Free AsSOciation}

\section{A. The Compact}

In the decades following the end of the nuclear testing program, the U.S. and Marshallese governments slowly progressed toward Marshallese independence ${ }^{84}$ and made initial efforts to provide health care to the many victims of the testing. ${ }^{85}$ The most significant step toward compensation to radiation victims, however, occurred simultaneously with attainment of RMI sovereignty when the Marshall Islands and the United States completed the Compact of Free Association. ${ }^{86}$ The Compact established the Republic of the Marshall Islands as a sovereign nation in free association with the United States. ${ }^{87}$ The nations finalized the Compact on June 25, 1983, dissolving the

84. In 1965, the Congress of Micronesia was formed. See Lee, supra note 15, at 407. In 1967, the Marshall Islands established the Political Status Commission to negotiate with the United States about the administration of the Trust Territory. See id. at 407-08. The RMI approved its constitution in a referendum on March 1, 1979 and inaugurated a parliamentary constitutional government on May 1, 1979. See id. at 408.

85. See Act of October 15, 1977, Pub. L. No. 95-134, 91 Stat. 1159.

Title I, \$104 provides in pertinent part:

(a) the Secretary [of the Interior] shall provide by appropriate means adequate medical care and treatment for any person [residents or their heir of Rongelap or Utirik Atoll] who has a continuing need for the care and treatment of any radiation injury or illness directly related to the thermonuclear detonation referred to in paragraph (a) of this section [Bravo].

Id.

Also, see the Act of March 12, 1980, Pub. L. No. 96-205, 94 Stat. 84 (amending Pub. L. No. 95-134) (a). In addition to any other payments or benefits provided by law to compensate inhabitants of the atolls of Bikini, Enewetak, Rongelap, and Utirik, in the Marshall Islands, for radiation exposure or other losses sustained by them as a result of the United States nuclear weapons testing program at or near their atolls during the period 1946 to 1958, the Secretary of the Interior (hereinafter in this section referred to as the 'Secretary') shall provide for the people of the atolls of Bikini, Enewetak, Rongelap, and Utirik and for the people of such other atolls as may be found to be or to have been exposed [emphasis added] to radiation from the nuclear weapons testing program, a program of medical care and treatment and environmental research and monitoring for any injury, illness, or condition which may be the result directly or indirectly of such nuclear weapons testing program. The plan shall set forth, as appropriate to the situation, condition, and needs of the individual atoll peoples: (1) an integrated, comprehensive health care program [emphasis added]including primary, secondary, and tertiary care with special emphasis upon the biological effects of ionizing radiation; ... (3) All costs associated with the development and implementation of the plan shall be assumed by the Secretary of Energy ...

87. See id. The compact sets up a special relationship between the two nations where the 
existing trusteeship agreement between the Marshall Islands and the United States and granting the RMI self-government. ${ }^{88}$

\section{B. The Section 177 Agreement}

In Section 177 of the Compact, the United States accepted responsibility for the damage the U.S. nuclear weapons testing caused in the Marshall Islands. ${ }^{89}$ As detailed in Section 177 of the Compact, a separate agreement for "the just and adequate settlement of claims," commonly known as the "Section 177 Agreement," was created to implement Section 177 of the Compact. ${ }^{90}$ The United States intended the Section 177 Agreement to provide a full settlement of all claims arising from the nuclear testing program conducted in the Marshall Islands during the trusteeship period. ${ }^{91}$ Article X, Section 1 of the Section 177 Agreement provides:

This Agreement constitutes the full settlement of all claims, past, present and future, of the Government, citizens and nationals of the Marshall Islands which are based upon, arise out of, or are in any way related to the Nuclear Testing Program, and which are against the United States, its agents, employees, contractors and citizens and nationals, and of all claims for equitable or any other relief in connection with such claims . . . which may be pending

RMI is a sovereign power, but the United States has granted the RMI access to the services of over forty U.S. domestic programs and a large per capita funding. See Boyce testimony, supra note 5. The United States takes responsibility for the RMI's security in return for foreclosure of third country access to the Marshall Islands for military purposes, known as "strategic denial." Id.

According to the DOE, the United States entered into the Compact for several reasons. See id. "[F]irst, ... the U.S. was obligated as administrator of the UN mandated Trust Territories, ..." Id. "[S]econd, in the Cold War environment of the mid-1980s, the United States was keen to bolster its security posture in the Pacific." Id. "Third, our agreement with the RMI ensured continued access to U.S. Army Kwajalein Atoll (USAKA)/ Kwajalein Missile Range ..." Id. The "Compact with the RMI provides for automatic renewal rights for an additional 15 years if the U.S. chooses to do so." Id.

88. See Compact of Free Association, Pub. L. No. 99-239, 99 Stat. 1770 (1986). See also Antolok v. United States, 873 F.2d 369 (D.C. Cir. 1989) (detailing the history of the Compact). The Compact officially went into effect October 21, 1986. See Proclamation 5564 Placing Into Full Force And Effect the Covenant With the Commonwealth of the Northern Mariana Islands and the Compacts of Free Association With the Federated States of Micronesia and the Republic of the Marshal Islands, Nov. 3, 1986, 51 FR 40399, available at 1986 WL 141919 (Pres.). See also Exec. Order No. 12569, 51 FR 37171, Oct. 16, 1986, available at $1986 \mathrm{WL}$ 141903 (detailing the responsibilities of the various federal agencies involved with the Compact's implementation).

89. See Compact of Free Association, Pub. L. No. 99-239, 99 Stat. $1770 \S 177$.

90. See id.

91. See Section 177 Agreement, Art. X, § 1. 
or which may be filed in any court or other judicial or administrative forum, including the courts of the Marshall Islands and the courts of the United States and its political subdivisions. ${ }^{92}$

In addition, Article XII of the Section 177 Agreement states: "All claims described in Articles $X$ and XI of this Agreement shall be terminated. No court of the United States shall have jurisdiction to entertain such claims, and any such claims pending in the courts of the United States shall be dismissed. ${ }^{93}$

Because the Section 177 Agreement states that it represents the means for the full settlement of all claims against the United States, U.S. courts held that Marshallese citizens could not bring claims against the United States arising from the nuclear testing. ${ }^{94}$ The victims, therefore, have no recourse other than the Compact and Section 177 Agreement. ${ }^{95}$ Accordingly, the interpretation and implementation of these agreements is vital to the welfare of the Marshallese people.

92. Id.

93. Section 177 Agreement, Art. XII.

94. See Juda v. United States, 13 Cl. Ct. 667, 689 (1987). Beginning in 1981, fourteen petitions were filed on behalf of approximately five-thousand inhabitants of the Marshall Islands in the United States Court of Claims for damages allegedly caused by the United States nuclear testing. See id. at 668 . The fourteen cases involved three groups of people: inhabitants of Bikini Atoll, inhabitants of Enewetak Atoll, and inhabitants of atolls and islands that were not used as atomic test sites. See id. at 669 . Originally, the Bikini claims of (1) takings in violation of the Fifth Amendment and (2) breaches of an implied-in-fact contract that arose in 1946 and which created fiduciary obligations owed to the people of Bikini, were held to be valid claims within the jurisdiction of the court under the Tucker Act (28 U.S.C. $\$ 1491$ (a)(1) (1982)). See id at 669. Likewise, the Enewetak people and the third group stated valid claims of implied in fact warranty and unlawful takings respectively. See id. The court subsequently held, however, that Article XII of the Section 177 Agreement by necessary implication amended the Tucker Act. See id. The consent of the United States to be sued in the Claims Court on plaintiff's taking claims and breach of contract claims that arise from the United States' nuclear testing program in the Marshall Islands had been withdrawn. See id. at 689. See also Nitol v. United States, $13 \mathrm{Cl}$. Ct. 690 (1987), (holding same effect of Article XII); Peter v. United States, $6 \mathrm{Cl} . \mathrm{Ct}$. 768 (1984) (holding Congress has the power to deprive the federal courts of subject matter jurisdiction over claims which do not involve constitutional violation). See generally Thomas Stewart Blackburn, Case Comment, International Law - Treaty Interpretation - Congressional Powerto Withdraw Jurisdiction, Antolok v. United States, 873 F.2d 369 (D.C. Cir. 1989), 14 SUFFOLK TRANSNAT'L L.J. 325 (1990) (discussing federal court jurisdiction over diversity actions, "[Congress] may give, withhold or restrict such jurisdiction at its discretion, provided it be not extended beyond the boundaries fixed by the Constitution.")

95. The Compact's fifteen-year term will expire in October 2001. See Boyce testimony, supra note 5. The State Department has stated that it will establish an Office of the Special Negotiator to be located in the Department of State which will house the interagency team that will conduct the Compact negotiations. See id. 


\section{THE INADEQUACY OF THE SECTION 177 AGREEMENT}

Although the Section 177 Agreement states that it encompasses the final settlement agreement of all claims arising out of the nuclear testing, Article IX of that agreement, entitled Changed Circumstances, permits the RMI to submit a request for additional compensation to the U.S. Congress for its consideration. ${ }^{96}$ Article IX of the Section 177 Agreement reads in its entirety:

If loss or damage to property and person of the citizens of the Marshall Islands, resulting from the Nuclear Testing Program, arises or is discovered after the effective date of this Agreement, and such injuries were not and could not reasonably have been identified as of the effective date of this Agreement, and if such injuries render the provisions of this Agreement manifestly inadequate, the Government of the Marshall Islands may request that the Government of the United States provide for such injuries by submitting such a request to the Congress of the United States for its consideration. It is understood that this Article does not commit the Congress of the United States to authorize and appropriate funds. ${ }^{97}$

In recent years, Marshallese officials have alleged that the funding provided by the Section 177 Agreement is manifestly inadequate.98 Accordingly, the RMI announced that it will submit a request for additional funding to the U.S. Congress for its consideration..$^{99}$ On May 11, 1999, Tony A. Debrum, Minister of Finance for the Republic of the Marshall Islands, spoke before the U.S. House of Representatives Resources Committee concerning the problems facing his nation. He proclaimed, "[i]f this Committee and the RMI Government had known at the time of the Compact negotiations what we have learned now as a result of the DOE document declassification process, I am certain that Congress and the RMI would have negotiated a radically different agreement than we have today. 100

96. See Section 177 Agreement, art. IX.

97. Id.

98. See Oscar Debrum testimony, supra note 64. See also Weisgall testimony, supra note 59 (referring to the health care funds as "wholly inadequate").

99. See Oscar Debrum testimony, supra note 64. See also Tony A. Debrum testimony, supra note 13 (explaining that the RMI desperately needs more financial assistance from the United States).

100. Tony A. Debrum testimony, supra note 13. 


\section{A. Loss or Damage to Property and Person of the Citizens of the Marshall Islands, Resulting from the Nuclear Testing Program, Which Arose or was Discovered after the Effective Date of the Section 177 Agreement}

It is difficult to separate damages resulting from the nuclear testing which arose or were discovered after execution of the Section 177 Agreement from those that the RMI should have reasonably known about at the time of the agreement's formation. RMI officials have not attempted to draw this fine line. Rather, RMI officials have emphasized two crises that they feel prove that the provisions of the Section 177 Agreement are manifestly inadequate: the inadequate health care available to the Marshallese people and the inadequate funds available to the Nuclear Claims Tribunal. ${ }^{101}$

\section{B. Injuries Inadequately Addressed by the Department of Energy's Health Care Program}

As mandated under Title I of the Compact, ${ }^{102}$ one specific segment of the Marshallese population, the 174 direct victims of Bravo, receive medical care from the Department of Energy's medical program. ${ }^{103}$ The RMI government asserts that the limited availability of the DOE's program placed a burden on the RMI's public health sector. ${ }^{104}$ Marshallese officials believe that the DOE medical program ${ }^{105}$ should consider harm to all Marshallese

101. See id. See infra Part VI.D for discussion of the Nuclear Claims Tribunal.

102. Compact of Free Association, Pub. L. No. 99-239, 99 Stat. 1770, Title I, art. I, $\S 103$ (h)(1) DOE Radiological Health Care Program.

103. See id.

[T]he President (either through an appropriate department or agency of the United States or by contract with a United States firm) shall continue to provide special medical care and logistical support thereto for the remaining 174 members of the population of Rongelap and Utrik who were exposed to radiation resulting from the 1954 United States therno-nuclear "Bravo" test, pursuant to Public Laws 95-134 "91 Stat. 1159" and 96-205 "94 Stat. 84." Such medical care and its accompanying logistical support shall total $\$ 22,500,000$ over the first 11 years of the Compact.

Id.

104. See Tony A. Debrum testimony, supra note 13 . The DOE medical program, which receives almost $\$ 2,000,000$ annually, is limited to 174 people - those from Rongelap and Utirik who are "acutely exposed," as defined by DOE. Id. RMI officials object to the fact that although Congress has taken responsibility for the damage resulting from the entire testing program, it has limited DOE medical care to only two affected atolls and eligibility to participate is limited to exposure solely from the Bravo test. See id.

105. While arguing for expansion of the DOE's program, Minister Debrum hinted at the underlying anger of the Marshallese people by stating, "I won't discuss the outrage and humiliation of the people for being forced into medical experiments designed to benefit 
citizens based on cumulative exposure from the testing program because radioactive fallout from the tests contaminated all of the Marshall Islands. ${ }^{106}$ The RMI named numerous groups "exposed" 107 to medium or low levels of radiation that need the DOE's care but are not included in the DOE's definition of "exposed." 108 The RMI claims that the expense of caring for all of the exposed groups is beyond its financial capability. ${ }^{109}$

In the Compact, the U.S. Congress reaffirmed the United States' commitment, through the DOE's program, to the 174 Bravo victims mandated by previous law. ${ }^{110}$ It is unlikely that the RMI did not realize the scope of the DOE's programs at the time of the Compact's formation because the specific provisions were part of the Compact. The RMI emphasizes the importance of monitoring the environment of all atolls, concentrating on the food chain and the health of all the affected peoples. "II The RMI asserts that it cannot adequately provide for the exposed

scientists not the patients because after years of this practice, DOE finally agreed to terminate the medical program run by a U.S. weapons laboratory." Tony A. Debrum testimony, supra note 13.

106. See id.

107. Among those groups exposed:

(1) Marshallese test site workers who supported the testing and clean-up activities on Enewetak and Bikini, including the most dangerous type of activities, such as ground-moving activities that re-suspended plutonium in the air; (2) The people of Bikini, Enewetak and Ronglep who were prematurely resettled; (3) the Rongelapese "control" group; (4) The people of Ailuk, Likiep, Meiit, Wotie, Wotho, Ujae and Uielang who received levels of radiation in the vicinity of the people from Utirik; (5) The children of the prematurely resettled communities whose parents were exposed to radiation and who were born into highly radioactive environments; (6) Any second illness in the 174 exposed Marshallese.

Id.

108. The differences concerning the DOE's definition of exposed is part of an ongoing debate over radiation measurement and definitions. See id. The RMI claims that Marshallese citizens have been harmed by inaccurate radiation measurement and definition by the U.S. govemment. See id. Atolls such as Mejit, Ailuk, Likiep, Wotho, and Ujelang fall into the Department of Energy's category of the "least amount of radioactive atoms." Id. As a result, they are disregarded in all medical care or environmental monitoring programs under the Compact. See id. The DOE's category, however, of "the least amount of radioactive atoms" in the Marshall Islands exceeds acceptable radiation exposure levels in the United States hundreds of times. See id. The RMI is forced to care for the radiation-related needs of all atoll communities beyond those recognized as acutely exposed due to the testing program. See id.

109. See id.

110. See Compact of Free Association, Pub. L. No. 99-239, 99 Stat. 1770, Title I, art. I, $\S 103(h)(1)$.

111. See Tony A. Debrum testimony, supra note 13. See also Oscar Debrum testimony, supra note 64 (reiterating the "pressing need" for more medical surveillance and radiological monitoring activities despite the exhaustion of the funding provided under Section 177 Agreement). 
communities if the extent of their exposure is unknown. ${ }^{112}$ However, because the RMI knew or should have known the scope of the DOE's services, these items should not be considered under the Changed Circumstances provision. If the radiological monitoring services ${ }^{113}$ or medical care have been poorly delivered, ${ }^{114}$ that would be a matter for normal diplomatic negotiations ${ }^{115}$ between the two nations, perhaps to be worked out during the Compact renegotiations. ${ }^{116}$

\section{Injuries Not Adequately Addressed by the Four Atoll Health Care Program}

The U.S. Congress created a medical program to care for the people of Bikini, Enewetak, Rongelap, and Utrik atolls in $1980 .{ }^{117}$ The program was never implemented as intended, ${ }^{118}$ but the U.S. Congress reaffirmed the

112. See Tony A. Debrum testimony, supra note 13.

113. The Lawrence Livermore National Laboratory operates the DOE's environmental monitoring program. See Boyce testimony, supra note 5. The program is led by Dr. William Robison, and the DOE asserts that the program "has become the standard by which dose assessment and radioecology programs are measured today." Id.

114. Much to the Department of Energy's credit, it has admitted that there were deficiencies in its medical program. See Seligman testimony, supra note 76. Starting in 1944, a team of U.S. doctors, organized under the Brookhaven National Laboratory (BNL), provided limited medical care to certain Rongelap and Utrik beneficiaries. See id. "The BNL team visited the Marshall Islands semi annually for medical missions lasting four to six weeks." Id. The program provided only "intermittent medical care" to the mandated patients and "had limited prospects of making sustained contributions to either their health or public health in general." Id. However, beginning in 1998, the DOE implemented a new program with the local governments of Rongelap and Utrik atolls to provide medical care that would be more responsive to their needs. See id. The program's goals include: (1) Providing preventative and innovative healthcare for the mandated population; (2) enhanced continuity in the delivery of healthcare; (3) establishment of a community advisory process for the program; (4) delivery of healthcare in a culturally appropriate manner; and improve overall service. See id.

115. The Marshallese and U.S. governments will soon be involved in negotiations; which will be held prior to the expiration of the Compact in 2001. See Boyce testimony, supra note 5. See generally Agreement Relating to Diplomatic Relations, With Related Notes, Sept. 6 , 1989, U.S.-Marshall Islands, available at 1989 WL 428700.

116. See Boyce testimony, supra note 5. In regard to which issues should be handled under Compact renegotiation, and those that could be addressed under the Changed Circumstances provision of the Section 177 Agreement, Boyce stated cryptically:

The Compact negotiations should be limited to what Congress and the Compact called for. Issues involving nuclear claims should remain separate and be dealt with in accordance with the terms of the Compact, including the subsidiary agreement and, if appropriate, through a request to Congress for consideration based on changed circumstances.

Id.

117. See Pub. L. No. 96-205 (94 Stat. 84 amending 95-134).

118. See Weisgall testimony, supra note 59. President Carter signed Pub. L. No. 96-205 into law in 1980. See id. The Interior Department, however, never implemented the program 
United States' commitment to the idea in the Compact. ${ }^{119}$ The Four Atoll Health Care Program (Four Atoll Program), after implementation by the RMI, faced several severe obstacles. First, because most Marshallese citizens are not covered by the DOE's health care program, a large portion of the Marshallese population looks to the Four Atoll Program for healthcare. ${ }^{120}$ Population growth in the Marshall Islands has exacerbated the problem. ${ }^{121}$ When the RMI signed the Compact the four atolls contained an estimated population of 2300 people. $^{122}$ As of 1997 , approximately five times as many people had enrolled in the program. ${ }^{123}$ This figure includes approximately 10,919 people from the four atolls as well as an additional 555 people from other atolls qualified for coverage. ${ }^{124}$

Certain U.S. officials have criticized the Marshall Islands for failing to establish eligibility criteria for the Four Atoll Program. ${ }^{125}$ The RMI contends that because the DOE's care is restricted and the Marshallese public health infrastructure is stretched beyond its capacity, virtually all of the people from the eligible atolls sought to enroll in the Four Atoll Program. ${ }^{126}$ The RMI further asserts that it is hard to imagine anyone from the four atolls who is "not affected by the consequences" of the testing program. ${ }^{127}$ Additionally, the RMI asserts that it did not foresee at the Compact's signing the extent to which health care costs would increase annually. ${ }^{128}$ Since the Compact's inception, the purchasing power of the $\$ 2$ million annual appropriation under the Section 177 Agreement has declined

despite repeated requests from Congress and the Marshall Islands. See id. The U.S. government placed the responsibility to implement the program upon the RMI in the Section 177 Agreement. See id.

119. See Compact of Free Association, Pub. L. No. 99-239, 99 Stat. 1770 (1986), Title I, $\S 103(\mathrm{j})$, which provides:

(1) Services provided by the United States Public Health Service or any other United States agency pursuant to section 1(a) of Article II of the Agreement for the Implementation of Section 177 of the Compact (hereinafter in this subsection referred to as the "Section 177 Agreement") shall be only for services to the people of the Atolls of Bikini, Enewetak, Rongelap, and Utrik who were affected by the consequences of the United States nuclear testing program, pursuant to the program described in Public Law 95-134 "91 Stat. 1159" and Public Law 96-205

"94 Stat. 84" and their decedents (and any other person identified as having been so affected if such identification occurs in the manner described in such laws) (emphasis added).

120. See Weisgall testimony, supra note 59.

121. See id.

122. Id.

123. Id.

124. Id.

125. See Tony A. Debrum testimony, supra note 13.

126. See id.

127. Id.

128. See id. 
dramatically. ${ }^{129}$ Unfortunately, the program receives no inflation adjustment. ${ }^{130}$ Currently, the Four Atoll Program has a budget that equates to approximately fifteen dollars per patient per month. ${ }^{131}$ Although the Compact entitles the RMI government to use the U.S. Public Health Service to bolster its health care sector, the RMI claims that due to U.S. budget cutbacks the Public Health Service informed the RMI that it does not have the resources to place doctors in the Marshall Islands. ${ }^{132}$

Section 177 of the Compact, to which the Changed Circumstances provision is applicable, does not specifically refer to the Four Atoll Program, but does state that "[t]he Government of the United States and the Government of the Marshall Islands shall set forth in a separate agreement [the 177 Agreement] provisions for . . . the continued administration by the Government of the United States of direct radiation related medical surveillance and treatment programs ...."133 In addition, the Preamble to the Section 177 Agreement refers to the language of Public Laws 95-134 and 96-205, purporting to establish an "integrated, comprehensive" health care system. ${ }^{134}$ From the language of those laws, the RMI government should have reasonably expected that the funding and programs provided by the Compact and the Section 177 Agreement would provide the "comprehensive" health care system promised. The RMI government stated that it does not have the expertise or the financial resources to provide health care for all its people suffering from nuclear testing related injuries. ${ }^{135}$ Minister Debrum stated, "we are almost no closer today than we were at the beginning of our relationship to providing for the health care needs of our radiation victims." 136 "Despite the fact that we have some of the highest incidences of radiogenic illnesses and cancers in the world, we don't have adequate hospitals, diagnostic equipment or even a cancer registry program in the Marshall Islands." 137

\section{Claims Inadequately Compensated by the Nuclear Claims Tribunal}

The Nuclear Claims Tribunal (Tribunal) is the mechanism created by the Section 177 Agreement to remedy property and personal injury claims resulting from the nuclear testing. ${ }^{138}$ The Tribunal's approach to personal

129. Id.

130. See id.

131. Id.

132. See id.

133. Compact of Free Association Act of 1985, Pub. L. No. 99-239, 99 Stat. 1770 (1986), Title II, art.VII § 177 (b).

134. Preamble, Section 177 Agreement.

135. See Tony A. Debrum testimony, supra note 13.

136. Id.

137. Id.

138. Section 177 Agreement, Article IV, Section 1 - Establishment and Operation of the 
injury claims is intentionally patterned after a similar U.S. statutory program that provided compensation for American civilian and military personnel harmed by the U.S. nuclear testing in Nevada. ${ }^{139}$ In the Radiation Exposure Compensation Act of 1990 (often referred to as the "Downwinders' Act"), ${ }^{140}$ the U.S. Congress found that fallout emitted from the nuclear tests conducted in Nevada exposed American civilians "to radiation that is presumed to have generated an excess of cancers among those individuals." 141 "In view of that finding, the Congress established a presumptive program of compensation for specified diseases contracted by the people who were physically present in the 'affected area' during the periods of atmospheric testing in Nevada. ${ }^{\text {142 }}$

The Tribunal determined that it would only be equitable if the Marshallese victims received the same type of statutory remedy. ${ }^{143}$ Accordingly, the Tribunal adopted compensable medical condition regulations providing for awards to people physically present in the Marshall Islands during the testing period and for those who were also medically diagnosed as having one of the thirty-four conditions. ${ }^{144}$

\section{Claims Tribunal:}

(a) The Government of the Marshall Islands, prior to the first anniversary of the effective date of this Agreement, shall establish a Claims Tribunal, in accordance with its constitutional processes and this Agreement. The Claims Tribunal shall have jurisdiction to render final determination upon all claims . . based on, arise out of, or are in any way related to the Nuclear Testing Program, and disputes arising from distributions under Article II and III of this Agreement. This section confers in the Claims Tribunal no jurisdiction over the United States, its agents, employees, contractors, citizens or nationals with respect to claims of the Government, citizens or nationals of the Marshall Islands arising out of the Nuclear Testing Program.

Id.

139. See Claims Approach, supra note 63. See also Oscar Debrum testimony, supra note 64 (reiterating the "Downwinders' Act" as the Tribunal's model, and further asserting that the Tribunal's funding is inadequate).

140. 42 U.S.C. $\$ 2210$. For discussion of the Nevada testing victims, as well as other groups of people exposed to radiation by the U.S. government, see William A. Fletcher, Atomic Bomb Testing and the Warner Amendment: A Violation of the Separation of Powers, 65 WASH. L. REV.285(1990); Leonard W. Schroeter, Human Experimentation, The Hanford Nuclear Site, and Judgment at Nuremberg, 31 Gonz. L. REV. 147 (1996); Trisha T. Pritikin, Hanford: Where Traditional Common Law Fails, 30 GoNZ. L. REV. 523 (1995).

141. Claims Approach, supra note 63.

142. Id.

143. See id.

144. See Nuclear Claims Tribunal: Claims, at http://www.tribunal-mh.org/claim.html (last visited Nov. 5, 1999) [hereinafter Tribunal Claims], detailing the Marshall Islands Nuclear Claims Tribunal Act of 1987. As originally adopted in 1991, the Act established a list of twenty-five medical conditions that were irrefutably presumed to be the result of the Nuclear Testing Program. Id. Based on subsequent scientific reports made available, the regulation was expanded to its present thirty-four conditions. Id.

These medical conditions are: Leukemia, cancer of the thyroid, cancer of the 
The Tribunal's presumptive program is warranted, according to the RMI government, because of the need for an efficient and cost-effective system of resolving personal injury claims where proof of causation would often be impossible because large amounts of the exposure data is not available. ${ }^{145}$ The presumptive standard applies to the entire Marshall Islands, not simply the atolls which have suffered the most severe contamination. ${ }^{146}$ The Tribunal concluded that given the vastly greater radioactive fallout of the tests in the Marshall Islands compared with those in Nevada, it was clearly justified in extending the presumption of exposure to everyone living in the Marshall Islands during the testing period. ${ }^{147}$

Oscar Debrum, Chairman of the Tribunal, asserts that the funding allocated to the Nuclear Claims Tribunal under the Section 177 Agreement is manifestly inadequate, ${ }^{148}$ thereby preventing the Tribunal from fulfilling its mandate of compensating the Marshallese victims. ${ }^{149}$ He claims there have been far more cases of radiogenic illnesses presented to the Tribunal than either nation was prepared for when they originally negotiated the Compact. $^{150}$ The situation is complicated by the realization that many radiation-related illnesses, latent for decades, are now beginning to appear

breast, cancer of the pharynx, cancer of the esophagus, cancer of the stomach, cancer of the small intestine, cancer of the pancreas, multiple melanoma, lymphomas, cancer of the bile ducts, cancer of the gall bladder, cancer of the liver, cancer of the colon, cancer of the urinary bladder, tumors of the salivary gland, non-malignant thyroid nodular disease, cancer of the ovary, unexplained hypothyroidism, severe growth retardation due to thyroid damage, unexplained bone marrow failure, meningioma, radiation sickness, beta burns, severe mental retardation, unexplained hyperarathyroidism, tumors of the parathyroid gland, bronchial cancer, cancer of the brain, cancer of the central nervous system, cancer of the kidney, cancer of the rectum, cancer of the cecum, non-melanoma skin cancer.

Id.

145. See Claims Approach, supra note 63. Despite requests by the RMI government, fallout measurements from the last two series of tests in the Marshall Islands (Operation Redwing in 1956 and Operation Hardtack $I$ in 1958, comprising fifty tests averaging nearly one megaton each) still remain classified. See id.

146. See id.

147. See id. The total yield of the sixty-seven tests conducted by the United States in the Marshall Islands is approximately 99 times greater than the total yield of the 87 atmospheric tests conducted in Nevada (approximately 108.5 megatons in the Marshall Islands compared to 1.1 megatons total in Nevada). Id. In addition, because of the environmental differences between an ocean lagoon and the Nevada dessert, the tests in the Marshall Islands created much larger amounts of fallout. See id. The amount of I-131 released at the Marshall Islands was $\mathbf{4 2}$ times greater than the Nevada test site. Id. I-13I is a radionuclide which concentrates in and may cause damage, including cancer, to the thyroid. See id.

148. See Oscar Debrum testimony, supra note 64.

149. See id.

150. See id. 
in the Marshallese population. ${ }^{151}$

As of April 30,1999, compensation totaling $\$ 67,700,000$ had been awarded to 1613 individuals. ${ }^{152}$ This amount represents approximately $\$ 22$ million more that the $\$ 45,750,000$ provided under the Section 177 Agreement for payment of compensation by the Tribunal during the fifteen year period of the Compact of Free Association. ${ }^{153}$ In addition, the Tribunal has yet to award any compensation for property damage, ${ }^{154}$ although three major class action suits are currently pending in the Tribunal's procedural system. ${ }^{155}$

Due to funding deficiencies, distribution of actual payments has necessarily been reduced. Funding shortages forced the Tribunal to reduce the pro rata annual payments in the years 1996 through1998 to $2 \%$, which brought the cumulative payment to $61 \%$ for all awards that had been approved prior to October $1,1996 .{ }^{156}$ For awards made on or after October 1,1996 , the Tribunal established a new initial payment rate of $25 \%$ of the net total of each award. ${ }^{157}$ In summary, the actual payment status for the majority (1274 people) of the Tribunal recipients is $61 \%$ of their award. ${ }^{158}$ Individuals awarded compensation between October 1, 1996 and September 30,1998 have received only $40 \%$ of their awards. ${ }^{159}$

Chairman Debrum voiced the RMI's view by stating, "[i]t is . . clear that the determinations already reached by the Tribunal render the provisions of the Section 177 Agreement manifestly inadequate. ${ }^{160}$ Many Marshallese people are dying from radiation-related illnesses without the compensation owed to them. ${ }^{161}$ Elderly Marshallese subjected to the testing program are dying without compensation whereas the radiation victims in the United States receive one-time payments when they are compensated for radiogenic illnesses. ${ }^{162}$

151. See id.

152. Id.

153. Id.

154. See id.

155. See id. The three class actions are the Enewetak Class Action, Bikini Class Action, and the Rongelap, Ailinginae, Rongerik, and Utrik Class Action. See id. The Tribunal will focus on: (1) just compensation for the loss of use; (2) restoration costs; and (3) consequential damages. See id.

156. Id.

157. Id.

158. Id.

159. Id.

160. Id.

161. See id.

162. See id. 


\section{E. Such Injuries Were Not and Could Not Reasonably Have Been Identified as of the Effective Date of This Agreement}

In 1983, at the time of the Compact's finalization, the RMI did not have all available information regarding the nuclear tests. ${ }^{163}$ Some information remains classified today, such as data pertaining to Operation Redwing and Operation Hardtack $I^{1}{ }^{164}$ Furthermore, the DOE did not release many of its documents concerning the testing program until after 1983. ${ }^{165}$ Perhaps in an effort to renew the Marshallese faith in U.S. truthfulness, ${ }^{166}$ the DOE recently implemented a program to make available one-million pages of nuclear testing documents through the DOE's Web site. ${ }^{167}$ These documents allow direct access by the RMI and the public to this important information. ${ }^{168}$ However, a million pages of scientifically complex information, made available long after the Compact was signed, is not much help to the health of the Marshallese people. RMI citizens will quite reasonably question whether they can trust any data offered by the DOE. ${ }^{169}$ Other non-DOE sanctioned data also became available after the Compact's formation. ${ }^{170}$ Damage disclosed to the RMI regarding Bikini Atoll serves as one example. ${ }^{171}$ But expertise, such as that possessed by the $\mathrm{DOE}$, is needed to interpret the findings.

It is not clear, however, how significant this information is to RMI's present assertion of injuries that "were not and could not reasonably have been identified as of the effective date" of the Compact. Only a careful review of the scientific data could determine if the new information reveals greater injury to the Marshallese people than the governments expected when

163. See Tony A. Debrum testimony, supra note 13.

164. See Claims Approach, supra note 63.

165. See 145 CONG. REC. H3063-02, H3064 (daily ed. May 12, 1999)(statement of Rep. Faleomavaega), available at 1999 WL 296150; 145 CONG. REC. H8115-03, H8117 (daily ed. Sept. 13, 1999) (statement of Rep.Underwood), available at 1999 WL 708989.

166. Some Marshallese citizens distrust the DOE in part because of the events surrounding Bravo. The AEC received a report about a change in the wind direction six hours before Bravo was detonated. See Eisenbud, supra note 44 . With full knowledge that winds were not headed northward to the open sea, but due east over Bikini's islands, the AEC proceeded to detonate Bravo. See id. Before Congress in 1999, Ralph Boyce of the DOE nevertheless referred to "sudden wind changes [that] sent radiation unexpectedly eastward ..." Boyce testimony, supra note 5.

167. See Seligman testimony, supra note 76.

168. See id.

169. See Weisgall testimony, supra note 59.

170. See id.

171. See 145 CONG. REC. H4334-01, H4335 (daily ed. June 24, 1997), available at 1997 WL 345477. Recently disclosed information previously withheld by the U.S. government revealed that the physical and radiological damage to Bikini Atoll caused by the U.S. nuclear testing program was more extensive than previously disclosed. See id. 
the Compact was signed. The DOE's actions, however, will likely arouse extra sympathy in the U.S. Congress for the Marshallese plight.

\section{CONClusion}

The Changed Circumstances provision of the Section 177 Agreement does not legally obligate the U.S. Congress to address a RMI request for additional funding. ${ }^{172}$ However, Congress has been sympathetic to the Marshallese plight. ${ }^{173}$ Accordingly, Congress will most likely examine the Marshallese grievances. In so doing, Congress will logically look to the requirements, or elements, of the Changed Circumstances provision to evaluate whether the RMI presents a prima facie case showing that the terms of the Section 177 Agreement are manifestly inadequate. An affirmative answer to that question would necessitate the requisite full scale investigation for a Congressional remedy. ${ }^{174}$

In the RMI's plea to Congress, it could credibly argue that injuries have been discovered which were caused by the nuclear testing but were not discovered until after the Compact and Section 177 Agreement were finalized. ${ }^{175}$ Furthermore, the RMI could reasonably argue that at least a portion of these injuries were not reasonably foreseeable due to the wealth of data that has become available due to new scientific studies, ${ }^{176}$ declassification of DOE documents, ${ }^{17}$ and the unknown extent of radiodonic diseases. ${ }^{178}$

Whether or not the RMI can produce sufficient evidence to convince Congress that the Section 177 Agreement is "manifestly inadequate" is unclear. That phrase is not defined in the Section 177 Agreement or in the Compact. In ordinary usage, manifest means "obvious," and adequate may be defined as "suitable or sufficient." 179 Thus, a common sense meaning of that phrase would be "obviously not sufficient." ${ }^{180}$ What is clear, however, is that Congress should be lenient in applying that standard to the RMI's petition for funding.

The disaster inflicted upon the Marshallese for the last fifty-four years has created a moral obligation. The United States owes an immense debt to

172. See Section 177 Agreement, Article IX, Changed Circumstances.

173. See Act of October 15, 1977, Pub. L. No. 95-134, 91 Stat. 1159;

Act of March 12, 1980, Pub. L. No. 96-205, 94 Stat. 84 (amending Pub. L. No. 95-134).

174. See Stayman testimony, supra note 5.

175. See Tony A. Debrum testimony, supra note 13.

176. See 145 CONG. REC. H4334-01, H4335 (daily ed. June 24, 1997), available at 1997 WL 345477.

177. See id.

178. See id.

179. WEBSTERS 21ST CENTURY DICTIONARY (1992).

180. The United States Supreme Court has generally held that words in a treaty are to be given their ordinary meaning. Chan v. Korean Air Lines, Lid., 109 S.Ct. 1676, 1678 (1989). 
the Marshallese people for their tremendous sacrifices that directly contributed to and continue to contribute to the United States' nuclear deterrent and ballistic missile defense capability. ${ }^{181}$ The Marshallese people made those sacrifices with their lives and homeland.

Notwithstanding Section 127 of the Compact, which purports to end any United States responsibility not outlined in the Compact, ${ }^{182}$ the U.S. government should also recognize a fiduciary duty to continue to help the Marshallese people for as long as they need it. ${ }^{183}$ During the trusteeship period, the Marshall Islands and the United States were not on an equal state to state relationship. ${ }^{184}$ Rather, the United States, because of its powerful status, "enjoyed special privileges in its administration of the Trust Territory ."185 In this relationship, the Marshallese people were "dependent on the United States as the administrator of the trust to act in good faith."186 The United Nations Charter, Articles 82 and 76, which created the International Trusteeship System, imposed this same fiduciary duty upon the United States to administer the trust for the ultimate benefit of these inhabitants. ${ }^{187}$ Because of the unequal nature of this relationship, there existed a fiduciary obligation that "imposed a higher standard and longer enduring duty of care upon the United States in its administration of its Trust Territories." 188 The United States failed to act as trustee in a manner consistent with that higher standard.

The United States abused the trust relationship by bombing the Marshall Islands. ${ }^{189}$ Additionally, the United States has allowed the Republic of the Marshall Islands to remain dependent upon the United States since the trusteeship began. The United States has moved the Marshall Islands toward independence in terms of sovereignty. But realistically, the RMI's nuclear injuries have created a different type of dependence that has greatly limited

181. See 145 CONG. REC. H3063-02, H3063 (daily ed. May 12, 1999), available at 1999 WL 296250.

182. Compact of Free Association, Pub. L. No. 99-239, 99 Stat. 1770 (1986), Title II \& 127, which provides:

Except as otherwise provided in this Compact or its related agreements, all obligations, responsibilities, rights and benefits of the Government of the United States as Administering Authority which have resulted from the application pursuant to the Trusteeship Agreement of any treaty or other international agreement to the Trust Territory of the Pacific Islands on the day preceding the effective date of this Compact are no longer assumed and enjoyed by the Government of the United States.

Id.

183. See Lee, supra note 15 , at 415.

184. See id.

185. Id.

186. Id.

187. See U.N. CHARTER arts. 82 and 76.

188. Lee, supra note 15 , at 415 .

189. See id. 
the RMI's self-sufficiency, and thereby its bargaining power to affect change for itself by diplomatic force. The RMI has been, and will continue to be, relegated to pleading to the U.S. Congress for more funding while politely pointing to the harm the RMI has suffered. This unfortunate situation would not be present if the United States had not placed the RMI in its present turmoil.

Because of these moral and fiduciary duties, whether or not legally enforceable, Congress should make every effort to deliver the needed assistance to the RMI. Minister Tony Debrum of the RMI, while announcing that Congress should consider the Changed Circumstances petition of the RMI Government, ${ }^{190}$ specifically put forward tentative requests to remedy the deficiencies of the U.S.-Marshallese agreements:

1. A supplemental ex gratia payment to the Nuclear Claims Tribunal, consistent with Section 105(c)(2) of the Compact, in order to make the full awards that the Compact envisions for personal and property damage; ${ }^{191}$

2. Infrastructure and institutional support for the RMI public health sector, including additional facilities, equipment, and trained personnel;

3. Expansion of eligibility for the DOE medical program;

4. An inflation adjustment for the four atoll health care program; ${ }^{122}$

5. A directive to the U.S. Public Health Service to provide doctors to the Marshall Islands; and

190. See Tony A. Debrum testimony, supra note 13. In addition to the above key requests, Debrum referred to some additional requests, although unlikely to fall under the Changed Circumstances provision:

(1) A directive to the Department of Energy to conclude a bilateral agreement on clean-up standards for resettlement and worker safety standards for Marshallese workers involved in clean-up activities. The clean-up standards should be equal to those used in the United States and monitored by an independent party; (2) A directive to the Department of Energy to put its environmental monitoring contractor in the RMI, Lawrence Livermore National Laboratory, out to bid; (3) Continued Committee representation at the annual meetings between the DOE and the RMI; (4) Training and education-programs in the fields of environmental science and radiation health.

Id.

191. Oscar Debrum calculated the immediate need to be approximately $\$ 22,900,000$, as of April 30, 1999, as the Tribunal had already awarded $\$ 67,700,000$, but the Section 177 Agreement provides only $\$ 45,750,000$ for the entire fifteen-year compact period. Oscar Debrum Testimony, supra note 64.

192. For the argument that the United States should run the health care program, as originally intended, see Weisgall testimony, supra note 59. 
6. A nationwide cancer registry program in the Marshall Islands. ${ }^{193}$

Each of these requests carries a significant financial price ${ }^{194}$ for the United States and consequently, the RMI's record of financial responsibility should be examined. Although there have been limited accusations of poor management by the RMI, ${ }^{195}$ Congress should have the burden to overcome the presumption that the RMI has prudently handled the $\$ 150$ million $^{196}$ originally granted under the Section 177 Agreement. ${ }^{197}$ Again, leniency should guide Congress in light of the overwhelmingly complex problems facing the young nation. ${ }^{198}$

The United States has given a substantial amount of assistance to the Marshallese people, and those efforts have been recognized. The RMI has repeatedly voiced its appreciation for Congress' aid. However, in light of the current deficiencies under the Section 177 Agreement, more funding is desperately needed. When Congress is asked for help by the Marshallese people, it should deliver the funds expeditiously. Priority should be given to those Marshallese currently suffering from radiodonic diseases, especially the elderly Marshallese citizens. ${ }^{199}$ Congress should remember why the Marshall Islands are again desperately in need of the United States' helping hand.

John C. Babione

193. Tony A. Debrum testimony, supra note 13.

194. The United States has spent large amounts of money on the Marshall Islands in areas other than health care. For example, in the restoration of Bikini Atoll, the $\$ 90,000,000$ the United States has provided for cleanup may be only half of what is necessary. See Oversight Hearings on Status of Nuclear Claims and Relations and Resettlement in the Marshall Islands, 1999: Hearings Before the House Comm. On Resources, 106th Cong. (1999) (statement of Henchi Balos, Bikini Senate), available at 1999 WL 16947529 [hereinafter Balos testimony].

195. See Boyce testimony, supra note 5.

196. Compact of Free Association, Pub. L. No. 99-239, 99 Stat. 1770 (1986), Title II $\S 177(\mathrm{c})$.

197. The people of Bikini have received part of the $\$ 150$ million. Their money management has been described as prudent. See 145 CONG. REC. H8115-03, H8117 (daily ed. Sept. 13, 1999), available at 1999 WL 708989.

198. While the RMI faces the normal problems of a developing nation, as well as the nuclear aftermath, it also has to combat PCB contamination. See generally Lee, supra note 15.

199. As of 1999,632 ( or 39\%) of the Marshallese citizens granted personal injury awards from the Tribunal were deceased. Oscar Debrum testimony, supra note 64.

* J.D. Candidate, 2001, Indiana University School of Law - Indianapolis; B.S., Environmental Science, Indiana University - Bloomington. I give all credit and thanks to my mother. My success is due to her enduring example of strength, kindness, and determination. 
